\title{
Public Regulation of Space Activities in Ukraine
}

\section{Larysa Soroka}

\author{
Ph.D. in Law, Associate Professor, Scientific Institute of Public Law \\ (Kyiv, Ukraine) \\ E-mail: lsorokakw@ukr.net \\ https://orcid.org/0000-0002-6979-6049
}

The article contains the results of the study of theoretical and methodological aspects of state regulation and administration of space activities in Ukraine. The concepts of "public regulation" and "public administration" are analyzed and their structural components are highlighted. The methods and measures of organizational activity of the state are defined with taking into account the tasks and features of its space activity. The definitions of state regulation and administration of space activities are given, and the main tools of organizational activity of the state in the space industry and ways of improvement are outlined.

Keywords: public regulation, public administration, space activity, state programs, law, organizational activity

Received: September 07, 2019; accepted: October 01, 2019

Advanced Space Law, Volume 4, 2019: 68-79.

https://doi.org/10.29202/asl/2019/4/7

\section{Introduction}

In the conditions of global globalization processes, which cover all spheres of public relations without exception (primarily economic, financial, information, migration, humanitarian), the system of public administration and regulation should not only be ready for the transformations that are taking place, but also to become their initiators and moderators. Therefore, the reforming of this system, i.e. a cardinal change of substantial properties, the introduction of new forms and methods of functioning, is a necessary condition for the implementation of the tasks. In spite of the fact that processes of improvement of organizational structure and forms and methods of activity of public administration bodies have permanent (constant and continuous) character, at present more than ever quantitative and substantive-and-qualitative changes in the system of public administration and public regulation in the economic sphere are necessary. These changes have been caused by the new trends in the development of the state in the conditions of world integration processes and the importance of directing its efforts to the formation of socially oriented economic relations [Nahrebelny, 2013].

(C) Soroka, Larysa, 2019 
After the disintegration of the USSR, there was a real opportunity to carry out space activities on a new basis. Ukraine as an independent subject of international law was interested in developing joint space projects and programs with other States and interstate associations. However, appropriate cooperation was not possible without a proper legal basis. And there was no such base in Ukraine traditionally: neither our own space legislation (in the days of the USSR both space activity and space legislation were structured at the All-Union level, and the Union republics were given the role of "screws of integral mechanism" managed from a single center), nor international bilateral and multilateral agreements on space cooperation our state had in the Soviet times. The soviet space system engineering and all space infrastructure of the former allied state practically were created together by the enterprises of Russia and Ukraine on the very close integration principles. After the subjects of the respective activity were under the jurisdiction of different states, many legal issues arose, including bilateral Ukrainian-Russian relations, in particular, regarding the division of former Soviet intellectual property for space objects.

In addition, commercialization trends, which have quickly captured the space field, have led to the emergence of a large number of non-state subjects in its arena, that have begun to play the role of independent actors in numerous space projects and programs, including international ones.

Consequently, the public administration bodies of the space industry faced the following questions: to ensure state control over the activities of non-state actors of space activities, to avoid spontaneity in the development of the relevant process, to protect state interests in the conditions of the international responsibility of states for the consequences of space activities of entities under their jurisdiction.

In addition to the problems mentioned above, in Ukraine for more than 20 years, the main attention has been paid to the preservation of the space industry and the implementation of the international space projects mainly, aimed at upgrading of the existing launch vehicles chiefly, adapting them to new launch sites. In the spacecraft segment, the main emphasis was placed on the completion of the production of spacecraft of the previous modifications. The introduction of modern technologies for the manufacture of spacecraft was carried out at a very slow pace. Other ministries and departments, enterprises of other branches of economy, and private companies were not involved in the sphere of space activity practically.

The reason for this was the orientation of the industry enterprises to financing at the expense of the state budget or attracting credits under the state guarantees, which did not allow to provide sufficient financing in the conditions of chronic deficit.

Such a state of affairs did not allow space activities to become the engine of innovative development of the economy of the country, it did not contribute to the formation of a synergistic effect from the introduction of high-tech and highly intelligent products, services, goods, etc.

\section{The concept of "public regulation" and "public administration" of space activities and their differentiation}

Article 4 of the Law of Ukraine "On Space Activities" defines one of the basic principles of state regulation of space activities, and Article 5 reveals the ways of state regulation and management in the field of space activities [On Space, 1996]. Although the terms "state regulation" and "public administration" are used in the Law, but what the legislator understands by these terms is not given. 
The terms "public regulation" and "public administration" are quite commonly used in scientific researches, political literature, in popular science editions, as well as in some normative acts. In spite of this, they remain determined not definitively, what leads to different interpretations, and, therefore, to the uncertainty of their essence.

Therefore, in determining the content and limits of state influence on the space sphere, as well as the possible directions of its development, it is advisable to analyze the ratio of the content of the categories "public regulation" and "public administration".

The relationship between them is either not determined by scientists, or revealed depending on their positions on general ideas about forms and methods of activity of the state. The relation between the concepts of "public regulation" and "public administration" should be considered as a derivative of the interpretation of the general categories of "regulation" and "management" [Administrative, 2004].

At the level of general management science, the concepts of "regulation" and "management" are almost never used as identical, however, the relationship between them is interpreted differently. It is generally accepted that regulation and management as social phenomena, having a common scope, imply different in character influences on the objects of management in order to achieve certain results, i.e. the realization of the set goals and objectives of managerial influence. At the same time, regulation covers a broader scope of organizational activity than management. Management means purposeful influence on the objects of management specifically, the use of methods that imply the subordination of these objects to management influence by the subject of management. Regulation is not so much related to the impact on the objects of management, but the environment. It provides a high degree of alternative behavior of managed objects [Administrative, 2004].

At the same time, regulation is sometimes regarded as one of the functions of management, which is caused by the theoretical uncertainty of the relation between these concepts. It is more appropriate to evaluate the relationship between the concepts of "regulation" and "management" in the context of not only their relationship but also the general concept of "organization" (or "organizational activity").

It is now widely accepted that the concept of "organization" is broader than that of "public administration" and "regulation". The latter are varieties of organizational activity, and therefore they have common features that reveal the essence of these concepts through determining the very nature of organizational influence on certain social objects. Both regulation and management reflect organizational activities aimed at ordering certain public interests and phenomena.

Thus, the legislator successfully classified the categories of "public regulation" and "public administration" to the types of organizational activity in the space industry, fixing them in section II "Organization of Space Activities" of the Law of Ukraine "On Space Activities" [On Space, 1996]. Therefore, "public regulation" is a broader concept than "public administration" because it covers a broader scope of organization activity of a state. Thus, public regulation and public administration are social phenomena that have both common and distinct features that have essentially one scope. The difference between these two concepts lies in the nature of the influence on social relations and the limits of such influence. Common features inherent in regulation and public administration, due to the fact that they are varieties of organizational activity of the state, aimed at the ordering of certain social phenomena, processes or objects. And the main difference between public administration and state regulation lies not in their object, but in the realization of what interests they provide [Tkach, 2012: 117]. 
That is, public administration is carried out in the areas where the public interest is first and foremost, and the state regulation is in those areas where it is necessary to strike a balance between public and private interests. State regulation provides for the establishment of certain standards, norms, limits, quotas, tariffs, which are generally binding on members of public relations and persons engaged in relevant activities.

It cannot be disagreed that state regulation of the space industry is a program of responsibility that realizes the tasks of the socio-economic and scientific progress of the state, increasing the well-being of citizens through the fulfillment of its mission by space industry enterprises, providing the state with the necessary resources and measures that will enable synthesis, combination of past, present, future, creation of a new reality of a more perfect world, where the spiritual and material component of human existence are balanced [Dzhur, 2015].

Thus, the public regulation of space activity is a type of organizational activity of the state, which consists in a set of means, methods by which state or non-governmental organizations to which the state delegated regulatory powers set principles, norms, rules for space activity and control (supervision) over such activities for the purpose of meeting public and private interests.

Public space management is a type of organizational activity of the state, which consists in a set of means, the methods by which public administration bodies exert power over the entities of space activity for the purpose of securing public interests.

Thus, public regulation and public administration of space activities have certain common features and differences.

The common features are, firstly, the fact that both public regulation and public administration are varieties of organizational activity of the state. Secondly, both public regulation and public administration use a definite set of tools and methods to streamline space activities.

As for the differences, they consist exactly in what facilities and methods are used for adjusting or administration of space activity.

State regulation is characterized by the creation of conditions for the activities of entities and objects of administration in a direction that is desirable for the state and in which the development of the administration system as a whole will occur. Moreover, state regulation provides several options for the future activity of the administrated objects, creating the opportunity to act more effectively. It includes laws, formal and informal regulations, and ancillary rules established by the state, as well as non-governmental or self-regulatory organizations to which the state has delegated regulatory powers in the field of space activities.

For example, the implementation of the state regulatory policy by the State Space Agency of Ukraine is carried out in accordance with the provisions of the Law of Ukraine "On the Principles of State Regulatory Policy in the Field of Economic Activity" [On the Principles, 2003] and other regulations on state regulatory policy to ensure the systematic and coherent adoption of regulatory acts in the field of economic activity, publicity, and transparency of the implementation of the state regulatory policy.

One of the main principles of the state regulatory policy is transparency and public opinion taken into account, which is based on openness to individuals and legal entities, their associations, actions of regulatory bodies at all stages of regulatory activity; the obligation to consider regulatory bodies initiatives, comments, and proposals submitted in accordance with the procedure established by law; bringing the adopted regulatory acts to the attention of individuals and legal entities, their associations; informing the public about the implementation of regulatory activities [Information, 2018]. 
Public administration, as it has been shown earlier, should be considered as a certain type of activity of the authorities of the state, which has a power and provides, first of all, organizing and managing influence on the objects of administration through the use of certain powers. The Law of Ukraine “On Space Activities" establishes the competence of the central executive body to ensure the formulation of state policy in the field of space activity, using such methods of administration as control (for example, it controls compliance with the requirements of the international treaties of Ukraine on the restriction and prohibition of nuclear weapons testing, nuclear testing weapons at foreign testing sites and peaceful nuclear missions (paragraph 9, part 2, article 6)) and surveillance (e.g. state surveillance of compliance with security requirements of space activities, as well as the training and certification of those who control the observance of space rules and the availability of the required level of security for space activities, as well as those investigating incidents and emergencies (Art. 20)) [On Space, 1996].

Thus, public regulation and public administration are used as specific forms of state influence on social and economic processes, which consists in the introduction of a set of measures aimed at achieving social and economic effect in the field of space activities.

\section{Main ways of public regulation and administration of space activity in Ukraine}

In accordance with the Law of Ukraine "On Space Activities" state regulation and administration in the field of space activity in Ukraine are carried out through: legislative establishment of basic principles, norms and rules of space activity; development of conceptual bases of state policy in the field of exploration and use of outer space for peaceful purposes and in the interests of state security; the formation of the National Targeted Scientific and Technical Space Program of Ukraine; planning and financing of space activities at the expense of the state budget of Ukraine, as well as facilitating the involvement of other funding sources not prohibited by the current legislation of Ukraine; targeted training at the expense of the state budget of Ukraine; foreign economic activity by subjects of space activities [On Space, 1996].

Let us briefly analyze all these instruments of organizational activity of the state in the space industry.

1. Legislative establishment of the basic principles, norms, and rules of space activities

The rules of space activity in Ukraine include standards of operational suitability of space objects, standards and normative documents governing the procedure of:

a) licensing of space activities;

b) certification and registration of space activities;

c) the organization, execution, and provision of space launches and flights;

d) supervising and controlling the safety of space launch and flight operations, and the operation of space technology;

e) environmental protection in the process of space activities;

f) conducting search, rescue, and rescue operations in the space industry;

g) conducting an official investigation of incidents and emergencies;

h) construction, operation, maintenance, and repairs of structures and equipment of ground infrastructure facilities;

i) training of space objects personnel;

j) the implementation of measures to protect space activities from unlawful interference with these activities [On Space, 1996]. 
The rules of space activity also include other normative acts, which are established by the relevant state bodies of Ukraine in accordance with their competence and, which are mandatory for all actors in space activities. These rules, as it has been noted already, regulate the activities in the space industry and its security, as well as compliance with the requirements for the protection of the intellectual property rights, state, military and trade secrets.

In addition to establishing norms and rules for the implementation of space activities, the state establishes direct prohibitions in the implementation of these activities. This concerns, first of all, the demilitarization of outer space. It is prohibited to place nuclear weapons and all other weapons of mass destruction in the orbit or in space in any way or to test such weapons and to use the Moon and other celestial bodies for military purposes. Secondly, it is prohibited to use of space technology as a means of influencing the environment and creating an immediate threat to human life and health.

And if such space activity within the framework of a separate project has led to human casualties, significant material losses or caused significant damage to the environment, it may be limited or prohibited in accordance with the current legislation of Ukraine.

2. Development of the conceptual framework of state policy in the field of exploration and use of outer space for peaceful purposes and in the interests of state security

The state policy should be understood as a set of value goals, state-administrative measures, decisions, and actions, the order of implementation of state-political decisions (goals set by the state power), and the system of state administration of the country's development [State Policy, 2014].

In order to increase the efficiency of space activities, to solve urgent problems of national security and defense, and to realize the geopolitical interests of the state, to promote the socioeconomic, scientific, educational and ecological-cultural development of society, to increase the prestige of Ukraine as a space state on the world stage, to turn the space industry of Ukraine into a multiplier of high-tech development of the domestic economy, the Conception of implementation of the state policy in the field of space activities for the period up to 2032 was approved by the Order of the Cabinet of Ministers of Ukraine of March 30, № 238-R. [Conception, 2011] (hereinafter the Conception).

The result of its implementation, that is, the quantitative measurement of its goals, is decisive for public policy. According to this Conception, the state has declared its results, methods, and ways of achieving these results. The main way to solve the existing problems of the space industry of Ukraine is seen through the improvement of the mechanism of providing state support and ensuring the investment attractiveness of space activities.

Analyzing the components of the organization of space activities in Ukraine, it can be noted that the state has taken the lion's share in ensuring the development of the industry through two interrelated processes - state support and investment attractiveness of space activities, which are noted in the regulatory acts.

In the conditions of cardinal narrowing of the sector of state property the state should carry out the corresponding policy adequate to these processes in the economic sphere, realizing its economic-organizational, social, and other functions in it. Such policy should be dominated by regulation, including disposition, control, coordination, forecasting, as well as the application of predominantly economic methods based on a rational and effective tax system that stimulates production and entrepreneurship, but it should not be pressed by imperative or dictatorship in its various forms, The budgetary, financial and credit, and public procurement systems also need to be improved [Nahrebelny, 2013]. 
In addition to the above-mentioned Conception, other legal acts have been adopted to support the space industry over the past decade. March 16, 2000 - the Law of Ukraine "On State Support of Space Activities" [On State, 2000]. This Law defined the principles of the state support for space activities in Ukraine and recognized the space industry as a priority component of the high tech sector of the economy to ensure the national interests of the state.

In order to improve the efficiency of space activities of Ukraine, the Order of the State Space Agency of Ukraine dated by May 21, 2015 №. 100 "The Strategy of Space Activities of Ukraine for the Period up to 2022" was approved [The Strategy, 2015].

All of these regulations are intended to solve the problems facing the space industry. But resolving space issues only by adopting regulations without proper government funding leaves all these efforts at the level of declaring.

3. Formation of the National Targeted Scientific and Technical Space Program of Ukraine

Space activities in Ukraine are carried out on the basis of the National Space Program of Ukraine, which is developed for a period of five years and approved by the Verkhovna Rada of Ukraine upon submission by the Cabinet of Ministers of Ukraine. The State Space Agency of Ukraine, together with the central executive authorities and the National Academy of Sciences of Ukraine, is responsible for the development of the National Space Program of Ukraine, based on the purpose and basic principles of space activity of Ukraine. To date, five Space Programs have been adopted and implemented in Ukraine. Work is underway on the new sixth National Space Program for 2018-2022, in accordance with the project, a structural restructuring of the industry is being prepared in order to increase the efficiency of its work as a whole, as well as the central office of the State Space Agency of Ukraine and individual enterprises. In this regard, relevant proposals are being made to the Government, amendments to the Laws of Ukraine that regulate space activities in the country are being prepared. But for today, the sixth program has not been adopted yet. Draft Law № 9457 [Draft Law, 2018] submitted at the end of 2018 by the Cabinet of Ministers of Ukraine was withdrawn on August, 29, 2019.

4. Planning and financing of space activities at the expense of the State Budget of Ukraine, as well as facilitating the attraction of other sources of financing not prohibited by the current legislation of Ukraine

Space activities are financed from the state budget, investments, and other sources. The amount of funding is determined by the national targeted space science and technology programs and other programs aimed at the development of space activities, based on the state budget.

Analysis of the budget programs and nationwide targeted space science programs has shown that none of them has been funded in full. The leadership of the State Space Agency of Ukraine has repeatedly stated that if the state does not change the approach to the space industry - "on a residual principle", there is no need to talk about Ukraine's place in the Space at all. [The State, 2018].

Even those funds, that were allocated, were not used effectively, the Accounting Chamber noted about more than once in its reports. For example, the audit of the effectiveness of Ukraine's obligations in the field of international scientific and technical cooperation and the framework program of the European Union for research and innovation "Horizon 2020", found violations of budget legislation, including misuse of funds and violations in planning [Report, 2018]. 
Thus, this area of state regulation and administration of space activities needs the most attention from public administration, because the gaps in planning and financing of these activities will negate all other attempts to bring the space industry to a high level.

Therefore, the national space program budget support system needs to be revised to support the specific projects and developments in the world-class technology. It is necessary to strengthen the commercialization of space services at the state level and to provide foreign policy support for the projects involving domestic aerospace companies. Without addressing these challenges, Ukraine risks to lose its space state positions fairly quickly [Anysenko \& Babina, 2018: 146].

5. Targeted training for space industry at the expense of the State Budget of Ukraine

The development of a market economy in Ukraine, the restructuring and conversion of the space rocket industry require the introduction of a scientifically based system of working with the space industry specialists as for their training, retraining, and advanced training. Indicators of the educational potential of personnel should correspond to those of industrialized countries; quality training of workers and industry professionals - to the requirements that are applied to workers by employers of the developed countries, that is, they must be competitive in the world market. The volume and structure of training should meet the needs of the industry, and funding should be provided at the expense of both budgetary and extra-budgetary revenues.

To ensure effective training, retraining, and advanced training of space industry professionals, it is necessary to develop an industry-wide complex plan for training and retraining of personnel within the provisions of the Law of Ukraine "On the National Space Program of Ukraine".

There is a need, in cooperation with international organizations and financial institutions as well as individual countries, to develop and implement the bilateral and multilateral plans for cooperation in the field of professional development of specialists, providing separate programs for specialists of the State Space Agency of Ukraine, mid-level specialists and managers of enterprises of the industry; organization of a system of short and medium-term seminars and training courses; attraction of highly qualified foreign and domestic specialists at the expense of the international funds.

\section{Licensing of space activities}

One of the main levers that the state has when presenting permits for space activities is the licensing of such activities. Ensuring the implementation of this administrative function has caused the need to create separate independent management bodies in various countries of the world, even in those that do not have a full cycle of space activities and the developed space industry, but which have their own spacecraft in the Earth orbit.

But in order to allow first, and then in the future to keep under its constant supervision and control the activities which it bears the international responsibility for, the effective system of state administration of the space industry was created in our state according to the Law of Ukraine "On Space Activities" of November 15, 1996. It was headed first by the National and since 2011 by the State Space Agency of Ukraine. According to Article 10 of this Law, implementing the norms of the international obligations of Ukraine, it was established the obligation of any space entities that carry out or intend to carry out these activities in Ukraine, or under the jurisdiction of Ukraine outside its territory, to obtain a license from the Agency for the right to exercise it.

The list of licensed space activities was enshrined in Article 9 of the Law of Ukraine "On Licensing of Certain Types of Economic Activity" [On Licensing, 2000] of June, 1, 2000. At 
the same time, Article 4 of the same Law established certain restrictions in the implementation of the certain licensed types of space activities, namely, those related to the development, testing, production, and operation of launch vehicles, including their space launches for any purpose: only state-owned enterprises were allowed to carry out such activities. The government approved and successfully implemented the procedure for licensing space activities, and at the departmental level — the relevant License Terms [On Approval, 2000]. The United Nations entities responsible for the peaceful exploration and use of outer space, the United Nations Office for Outer Space Affairs and the Legal Subcommittee of the United Nations Committee on the Use of Outer Space, were informed about the introduction of the above-mentioned procedure for licensing space activities [Malysheva, 2016].

The State Space Agency of Ukraine, which is the central executive authority that ensures the formation and implements state policy in the field of space activity, has lost the authority to license such types of space activities as the development, testing, production, operation of rockets, spacecraft and their components, terrestrial complex management of spacecraft and its constituent parts in connection with the entry into force on June 28, 2015, the Law of Ukraine of March 2, 2015, "On Licensing of Commercial Activities" [On Licensing, 2015]. In Article 7 of the relevant Law, any space activity was not found among the 30 licensed activities [On Licensing, 2015].

In addition, from February 27, 2019, the Draft Law "On Amendments to Some Laws of Ukraine on Demonopolization and Development of Space Activities" was registered under the number 10096, in the explanatory note of which it is proposed "...the mechanism for licensing space activities should be replaced by a mechanism for issuing free permits for testing and launching launch vehicles, launching or ensuring the launch of a spacecraft, the return of a spacecraft or its components, for example, from the earth orbit or outer space to the Earth, the management of a spacecraft [On Amendments, 2019]. We agree that the state monopoly on space activities in today's conditions should be abolished, but licensing is a necessary tool of state control.

The license is issued by the competent state authorities for the implementation of a certain type of activity or certain operations, and which are administrative acts of state regulation of business activity in the country. The Commercial Code of Ukraine establishes that licensing is a means of state regulation in the field of business, aimed at ensuring a unified state policy in this area and protecting the economic and social interests of the state, society, and individual consumers [Commercial Code, 2003].

Thus, we believe that it is necessary to demonopolize the space industry and allow commercial structures to participate in space activities, but the state should retain the right to control such activities using an effective licensing mechanism. To resolve the existing gaps in the current legislation, it is necessary to amend the Law of Ukraine "On Licensing of Commercial Activities" and establish requirements for licensing the development, testing, production, operation of rockets, spacecraft and their components, ground-based spacecraft control system and its components.

7. Control over implementation of foreign economic activity by subjects of space activity

Ukraine's international obligations on ensuring the missile technology control regime are reflected in the Law of Ukraine "On State Control over International Transfers of Military and Dual-Use Goods" [On State, 2003] and Resolution of the Cabinet of Ministers of Ukraine dated January 28, 2004 № 86 "On Approval of the Procedure for State Control over International Transfers of Dual-Use Goods" [On Approval, 2004], that raised the legal regulation of relations 
in the sphere of export control to the legislative level and established additional mechanisms of state regulation in this sphere, which correspond to the global practice.

At the same time, with regard to the "insurance" of space activities, its transfer to the rails of sustainable development, our state is not able yet to solve the contradictions of domestic producers by economic and legal methods: how to produce competitive products, adhering to the relevant international obligations in the field of sustainable development. First of all, it concerns: projects to create promising rockets - carriers with the safe components of rocket fuel, and the adoption at the national level of Rules for the Prevention of Contamination of Outer Space. The prospects of reconciling the latter due to the significant rise in cost of space technology and the inability to recoup additional costs for manufacturers of this equipment by the state are quite problematic.

The conclusions about the increasing role of the state in the space industry have been repeatedly drawn in the scientific publications [Krichevsky \& Udartsev, 2019]. Therefore, the development of the global space market, which is tightly associated with the latest technology and often has global implications, as well as the consolidation of private enterprises in the market demand: to develop fundamentally new approaches to issues about the control of those entities at the national and international levels, and their legal status; attention to issues of the financial security of responsibility of States for space activities, the prevention of harm and its compensation (that is, the need for the introduction of the "top" of mandatory insurance); additional mechanisms to limit the spread of missile technology. These circumstances also cannot but cause increased attention of states to the establishment of additional instruments of state regulation of activities in the exploration and use of outer space at the present stage of development of commercial space.

\section{Conclusion}

Thus, the analysis of the tendencies of development of national legislation on space activity regulation gives grounds to state that the increased requirements for the mechanisms of state regulation of this activity in modern conditions lag behind the needs of time. At the same time, the norms and principles of "classical" international space law are fully implemented in the domestic law for carrying out of the international obligations. Namely, Articles 3-25 of the Law of Ukraine "On Space Activities" [On Space Activities, 1996], which among other things introduces such mechanisms of state regulation of space activities as the permissive nature (licensing) of this activity, its program-planned bases of organization and implementation, the need for registration and certification of space technology, the introduction of compulsory insurance of space activities, the expansion of the framework of international cooperation and so on. But modern scientific researches and practice show that the main objectives of state regulation and administration of space activities should be: strengthening of legal protection of investors in Ukraine; introduction of tax and other incentives for the formation of proposals for long-term investment resources; demonopolization of the state for space activities; return of state control functions for space activities of all subjects through the mechanism of licensing of such activities; more clear regulation of the property rights to the investment objects and creation of transparent integration of such objects.

Within the framework of one article it is difficult to consider all the problematic issues facing the space sphere, so they will be studied in our subsequent studies. 


\section{References}

Administrative Law of Ukraine. Academic course: textbook: in two volumes. Volume 1. Common part. Ed. Board: V. B. Averyanov, 2004: 64-66.

Anysenko, Olga and Diana Babina. Development of space industry of Ukraine. Agrosvit, № 11, 2018. http://www.agrosvit.info/pdf/11_2018/12.pdf

Commercial Code of Ukraine: Law of Ukraine of January 16, 2003. №. 436-IV. https://zakon. rada.gov.ua/laws/card/436-15/find? Text =\% EB\% B3\% F6\% E5 \% ED\% E7

Conception of Implementation of the State Policy in the Field of Space Activities for the Period up to 2032: was approved by the Order of the Cabinet of Ministers of Ukraine of March 30, 2011, № 238-R. https://zakon.rada.gov.ua/laws/show/238-2011-\%D1\%80

Draft Law on Approval of the National Target Scientific and Technical Space Program of Ukraine for 2019-2023, № 9457 of 28.12.2018. http://w1.c1.rada.gov.ua/pls/zweb2/ webproc4_1?pf3511=65308

Dzhur, Olga. Government Regulation of Enterprises of Space Industry of Ukraine: New Realities and Challenges. Effective Economy, №1, 2015. http://www.economy.nayka. com.ua/?op=1\&z=3748

Information on the implementation of the state regulatory policy by the State Space Agency of Ukraine in 2018. http://www.nkau.gov.ua/ua/activity/rehuliatorna-polityka/derzhavnarehuliatorna-polityka/1290-zvity

International Center for Space Law Institute of State and Law the name of V. M. Koretsky of the National Academy of Sciences of Ukraine, 2019 http://idpnan.org.ua/mijnarodnij_ centr_kosmichnogo_prava.html

Krichevsky, Sergey and Sergey Udartsev. Space State on Earth and Beyond: Philosophy, Models, Experience and Prospects. Philosophy and Cosmology, Vol. 23. 2019: 30-52. https://doi.org/10.29202/phil-cosm/23/4

Malysheva, Natalia. Is it necessary to "deregulate" the sphere of space activity? Public Law, № 1, 2016. Pp. 90-95.

Nahrebelny, Volodymyr. Issues of state governance \& state regulation transformation in the sphere of economy. Bulletin of the National Academy of Legal Sciences of Ukraine, № 2 (73), 2013. P. 133-141 http://www.iepd.kiev.ua/wp-content/uploads/2016/08/visnik natsional_noyi_akademiyi pravovikh_nauk_ukrayini_2013.pdf

On Amendments to Some Laws of Ukraine on Demonopolization and Development of Space Activities: Draft Law, №10096 of 02.27.2019. http://w1.c1.rada.gov.ua/pls/zweb2/web proc4_2?id=\&pf3516=10096\&skl=9

On Approval of the License Terms for the Development, Testing, Production, Operation of Launch Vehicles, Spacecraft and their Components, Terrestrial Space Infrastructure and its Components, Equipment that is Part of the Space Segment of Satellite Systems: Order of the State Committee of Ukraine Regulatory Policy and Entrepreneurship and the National Space Agency of Ukraine, № 79/215, 19.12.2000. https://zakon.rada.gov. ua/laws/show/en/z0966-00?lang=en

On Approval of the Procedure for State Control over International Transfers of Dual-Use Goods: Resolution of the Cabinet of Ministers of Ukraine of January 28, 2004 № 86 (as amended by the Cabinet of Ministers of Ukraine resolution of October 24, 2018 № 974). https://zakon.rada.gov.ua/laws/show/86-2004-\%D0\%BF 
On Licensing of Certain Types of Economic Activity of 01.06.2000, № 1775-III. https://zakon. rada.gov.ua/laws/show/1775-14

On Licensing of Commercial Activities: Law of Ukraine of 02.03.2015, № 222-VIII. https:// zakon.rada.gov.ua/laws/show/222-19

On Space Activity: Law of Ukraine of 15.11.1996, №502/96-VR, 1996. https://zakon.rada. gov.ua/rada/show/502/96-\%D0\%B2\%D1\%80

On State Support of Space Activities: Law of Ukraine of March 15, 2000, № 1559-III. https:// zakon.rada.gov.ua/laws/show/1559-14

On State Control over International Transfers of Military and Dual-Use Goods: Law of Ukraine of February 20, 2003, №.549-IV. https://zakon.rada.gov.ua/laws/card/549-15

On the Principles of State Regulatory Policy in the Field of Economic Activity: Law of Ukraine of 11.09.2003 №1160-IV. https://zakon.rada.gov.ua/laws/card/1160-15

Report of the Accounting Chamber of Ukraine, 2018. https://rp.gov.ua/upload-files/Activity/ Reports/2018/ZVIT_RP_2018.pdf

State Policy. National Academy of Public Administration under the President of Ukraine, 2014. 448 p. http://academy.gov.ua/NMKD/library_nadu/Pidruchnuiky_NADU/9fa81bc0991f-47e7-817d-a853b8627f97.pdf

The Strategy of Space Activity of Ukraine for the Period up to 2022: approved by order of the State Space Agency of Ukraine from May 21, 2015 № 100. https://zakon.rada.gov.ua/ $\mathrm{rada} / \mathrm{show} / \mathrm{v} 0100814-15$

The State Space Agency of Ukraine spent the lion's share of its budget in 2017 on repayment of loans. UNIAN, 2018. https://www.unian.ua/economics/industry/10040624derzhkosmos-ukraini-levovu-chastku-svogo-byudzhetu-v-2017-roci-vitrativ-napogashennya-kreditiv.html

Tkach, Mary. State regulation and public administration: correlation of concepts. Entrepreneurship, economy and law, 2012. №8, pp. 110-119. http://pgp-journal.kiev. ua/archive/2012/08_2012.pdf 